\title{
MEDIA TERPADU DALAM PEMBELAJARAN BAHASA INDONESIA DI SEKOLAH DASAR
}

\begin{abstract}
Zulela MS
Abstract

The aim of this research is to fmd out the effect of instructional approach toward the result of narrative writing of fifth grade elementary school student. The research compared two approaches: Process Skill Approach (PSA) and Goal Oriented Approach (GOA) group of students who study. The result of the research are. (1) There is a significant difference between group of students who study with $R A$ by $F o=9.8401>F t=4.20$. (2) There is a significant difference between the result of narrative writing by group of student who has high interest in reading and study with Goal Oriented Approach (GOA) and the group of student who has high interest in reading and study with Process Skill Approach by Fo 6.3161> F t0.643. (3) There is a significant difference between the result of writing by group of student who has low interest in reading and study with Process Skill Approach and the result of writing by group of student who has low interest and study with Goal Oriented Approach by F o 12.2084> Ft 0.0643. (4) There is and interaction between the learning approach and reading interest toward writing of fifth grade elementary school student by Fo $84.6164>$ Ft 4.20. Based on that analysis, we can see that the skill process approach is more effective, entirely and for the student who has low reading interest in reading $G O A$ is more effective.
\end{abstract}

Kata kunci: menulis karangan, pendekatan proses

\section{PENDAHULUAN}

Sekolah dasar merupakan penggalan pertama dari pendidikan dasar. Dengan demikian sudah seyogyanya pendidikan di sekolah dasar dapat membentuk landasan yang kuat dalam pendidikan. Hal ini sejalan dengan Undang-Undang Sistem Pendidikan Nasional 2003, yang mengatakan bahwa; Pendidikan dasar merupakan jenjang pendidikan yang melandasi jenjang pendidikan menengah (Hamid. Dedi. UU No.20 Tahun 2003 Sistem Pendidikan Nasional, Durat Bahagia, 2005, hal.2). Ini berarti bahwa Sekolah Dasar harus membekali lulusannya dengan kemampuan dan keterampilan dasar yang kuat, yang di antaranya adalah kemampuan proses strategis.

Salah satu kemampuan proses strategis adalah keterampilan berbahasa. Dengan keterampilan berbahasa yang dimiliki, siswa dapat menimba berbagai ilmu pengetahuan, mengapresiasi seni, serta mengembangkan diri secara berkelanjutan. Selanjutnya, dengan bahasa, siswa dapat berintegrasi dengan lingkungannya sesuai dengan kodrat manusia sebagai makhluk sosial.

Keberhasilan pendidikan di sekolah dasar akan memberikan dampak pada keberhasilan dalam jenjang pendidikan berikutnya. Untuk mencapai keberhasilan itu, semua yang terkait dengan pendidikan di Sekolah Dasar khususnya, sudah seharusnya ikut serta memperbaiki unsur-unsur yang berhubungan dengan peningkatan mutu pendidikan. Ini berarti bahwa sekolah dasar harus membekali lulusannya dengan keterampilan/kemampuan dasar yang kuat, yang di antaranya adalah kemampuan proses strategis.

Dalam hubungan ini, penulis ingin menyajikan salah satu strategi dalam peningkatan kualitas pembelajaran di sekolah dasar dengan berpedoman pada kecenderungan siswa sekolah dasar, yakni strategi dalam pengadaan media secara terpadu atau pembelajaran terpadu. Hal ini diangkat, karena menurut pengamatan penulis di beberapa SD tempat para mahasiswa PGSD PPL, sebagian besar guru SD tidak menggunakan media kecuali buku ajar, khususnya dalam pembelajaran bahasa Indonesia. Mereka (para guru) beranggapan bahwa media dalam pembelajaran bahasa Indonesia itu sulit. Padahal media dalam pelajaran apapun sebenarnya dapat digunakan sebagai media dalam pembelajaran bahasa Indonesia. Untuk mengatasi hal itu, maka berikut ini penulis akan menyajikan beberapa contoh media dalam mata-mata pelajaran lain yang juga digunakan sebagai media dalam pembelajaran bahasa Indonesia.

\section{PEMBAHASAN}

\section{Kecenderungan Siswa Sekolah Dasar}

Dalam hubungan dengan proses belajar, anakanak usia Sekolah Dasar, mempunyai kecenderungan seperti; (1) beranjak dari hal-hal yang konkrit, (2) 
memandang sesuatu yang dipelajari sebagai suatu keutuhan, (3) melalui proses manipulatif, (4) berkembang melalui proses tahapan yang hierarki (Srini, I., 1995, hal.3).

Bertitik tolak dari kecenderungan di atas, maka untuk meningkatkan pelaksanaan pembelajaran di Sekolah Dasar salah satu pendekatan yang tepat untuk dipergunakan adalah pendekatan pembelajaran terpadu. Dengan pendekatan pembelajaran terpadu, siswa akan menerima pelajaran tersebut secara utuh, menyeluruh, sesuai konteksnya dan tidak terkotakkotak. Karena itu, dalam pembelajaran guru sebagai fasilitator harus berusaha memberikan pelayanan agar materi yang disajikan yang berorientasi dari kompetensi yang akan dicapai, tepat guna dan sasaran yang dikehendaki akan tercapai serta individu siswa akan berkembang secara utuh dan menyeluruh. Untuk mencapai hal ini salah satu caranya adalah dengan menggunakan media pembelajaran. Dikatakan demikian sesuai dengan pendapat Azar Arsyad (2006: 5-6) bahwa media merupakan komponen sumber belajar atau wahana fisik yang mengandung materi instruksional di lingkungan siswa yang dapat merangsang siswa untuk belajar.

Selain itu, hal lain yang harus dicermati guru dalam melaksanakan pembelajaran di SD terutama di kelas awal, adalah bahwa pembelajaran harus kongkrit dan manipulatif. Ini berarti bahwa pembelajaran yang disajikan tersebut harus menggunakan alat bantu (media) konkrit baik sederhana maupun modern, baik benda asli maupun tiruan. Sederhana mulai dari apa yang ada di lingkungan sekitar, bila dikemas dengan baik dan tepat (sesuai dengan tema) maka akan dapat membantu siswa dalam memahami inti pelajaran (lebih lanjut akan diberi contoh pada bagian berikut).

Selanjutnya, selain kedua hal di atas maka yang harus dipedomani oleh guru dalam menyajikan pelajaran adalah bahwa pelajaran yang diberikan harus disajikan secara hierarki atau melalui tahapan yang jelas dan sesuai dengan urutan (tidak melompatlompat), hal ini sesuai dengan prinsip pendekatan spiral; mulai dari yang mudah ke sukar, yang dekat ke jauh, yang sederhana ke kompleks dan seterusnya.

Semua unsur di atas, sebaiknya dikemas dengan berpedoman pada pendekatan DAP (Developmentally Appropriate Practice) yang dikemukakan Sue Bredekam, maksudnya; pembelajaran bagi siswa kelas awal SD hendaknya memperhatikan perkembangan sesuai usia (secara umum) dan sesuai individu (setiap anak mempunyai keunikan/kekhasan sendiri).

Khusus dalam pelaksanaan pembelajaran bahasa Indonesia di SD, menurut data empirik sebagian besar guru mengajar hanya menggunakan buku ajar saja. Hanya menggunakan buku ajar yang tidak bervariasi tetapi cenderung yang sama dari waktu ke waktu. Hal ini menurut pengamatan penulis disebabkan faktor ketidaktahuan terhadap anak dan dunianya dan kurangnya pemahaman tentang konsep pembelajaran dan juga sebagian berpandangan bahwa buat apa repot-repot, karena teman lain juga begitu. Paradigma mengajar seperti inilah yang harus diubah total, jika guru tersebut tidak mau dipinggirkan. Untuk itu, melalui tulisan ini penulis secara praktis akan menyajikan contoh-contoh penggunaan media terpadu sebagai alat bantu dalam pembelajaran bahasa Indonesia di SD, yang diharapkan dapat membantu guru SD khususnya dan guru pada umumnya dalam merencanakan dan melaksanakan pembelajaran khususnya pembelajaran bahasa Indonesia di SD.

\section{Media Terpadu dalam Pembelajaran Bahasa Indonesia}

Menurut kenyataan, yang merupakan hasil wawancara dengan guru SD di sekolah yang dijadikan tempat PPL mahasiswa D II PGSD FIP UNJ, para guru SD sebagian besar berpendapat bahwa media pembelajaran yang sulit diadakan adalah media dalam pelajaran bahasa Indonesia. Mengapa mereka berkata demikian? mereka hanya tahu bahwa media bahasa hanya terbatas pada gambar-gambar, kartu kalimat, kartu kata dan kartu huruf. Selain itu media bahasa itu mahal yaitu laboratorium bahasa, tape, kaset-kaset dan televisi. Pendapat ini, sebenarnya sangat keliru, karena bahasa adalah pelajaran yang strategis, artinya pelajaran yang dapat menjembatani semua pelajaran (pengantar untuk semua pelajaran). Oleh sebab itu, maka semua media dalam pelajaran lain, baik IPA(sains), matematika, PKPS, seni dan lain-lain juga dapat dijadikan media dalam pembelajaran bahasa Indonesia dalam semua aspeknya; menyimak, berbicara, membaca, dan menulis.

Sehubungan dengan hal di atas, penulis menegaskan bahwa hakikat bahasa adalah alat untuk mengungkapkan pikiran, perasaan, dan bahasa juga merupakan alat penalaran. Jadi maksudnya, apa yang terkandung dalam pikiran seseorang, dapat diungkapkan dengan memilih kata yang tepat dan dirangkai dalam kalimat yang baik agar dapat dipahami oleh pendengar/pembaca. Jadi bahasa merupakan ucapan/tulisan yang mewakili sesuatu yang ada dalam pikiran. Misalnya di dalam otak terpikir buah pisang, (tanpa berkata), tunjukkan gambar pisang. Orang yang melihat (siswa) dapat 
menyebutkan namanya dengan benar (dalam bahasa apa yang dikehendaki), juga dalam bentuk apa ungkapan yang diinginkan; cerita tentang pisang, pendapat, atau jenis buah apa dan lain-lain. Inilah yang disebut konkrit, dan dapat dikembangkan menjadi media pembelajaran.

Untuk lebih jelasnya, di bawah ini penulis akan menyajikan contoh-contoh media pembelajaran mata pelajaran lain di SD yang digunakan sebagai media dalam pembelajaran bahasa Indonesia.

\section{Media Mata Pelajaran Matematika}

Dalam hubungan ini penulis mulai dengan media matematika yang selama ini dianggap mempunyai kesenjangan yang jauh dengan bahasa Indonesia.

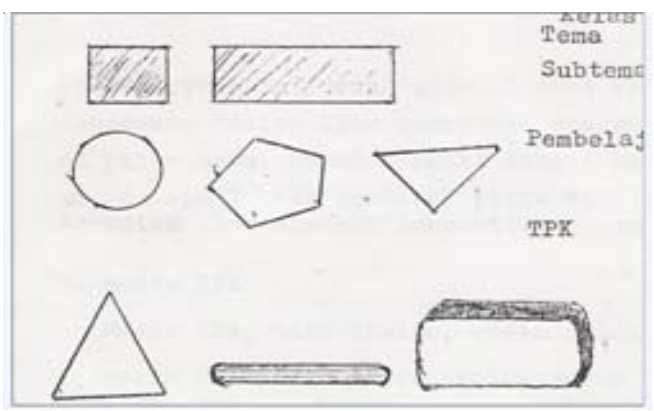

Gambar 1. Media alat bangun Ruang

Mata Pelajaran : Bahasa Indonesia

Kelas : IV

Tema/subtema : Lingkungan / lingkungan sekitar Indikator : Menulis deskripsi tentang benda di sekitar kita

Pelaksanaan pembelajaran di atas, dapat dimulai dengan; siswa mengamati bentuk-bentuk bangun datar seperti yang diperlihatkan, kemudian siswa ditugasi menginterpretasikan bentuk apakah yang berada di lingkungan mereka yang menyerupai bentuk-bentuk itu (yang diperlihatkan). Maka akan muncul jawaban siswa "lapangan bola segi empat panjang, meja bundar, ... dan seterusnya", setelah itu siswa disuruh menceritakan secara singkat apa manfaat/guna/pendapatnya terhadap benda tersebut. Hal ini dapat dituntun dengan pertanyaanpertanyaan; seperti apa saja yang ada di lapangan bola, apa gunanya, berapa luasnya dst. Selain itu, siswa dapat pula disuruh membedakan benda apa yang bulat, bundar, panjang-pendek, dst. Selanjutnya siswa disuruh menuliskan dengan bimbingan dan secara bertahap; kalimat, paragraf, dan seterusnya sampai bentuk karangan.
Dengan strategi demikian, siswa tidak akan kekurangan materi untuk menulis, karena dituntun dengan hal-hal yang konkrit dan telah dikenalnya.

\section{Media Pendidikan Kewarganegaraan dan Pengetahuan Sosial (PKPS)}

Salah satu media dalam pelajaran PKPS adalah "rumah", baik berupa gambar maupu dalam bentuk rumah mini. Dalam PKPS digunakan untuk mengajarkan arah angin, letak geografis dan lain-lain. Dalam pembelajaran bahasa Indonesia dapat dilaksanakan sebagai berikut.

Kelas :III

Tema/subtema : Kesehatan/Keindahan

Aspek(Fokus) : Berbicara (mengemukakan pendapat)

Indikator $\quad$ : Menjelaskan masalah aktual yang terjadi di lingkungan sekitar rumah/ tempat tinggal secara runtut.

\section{Pelaksanaan:}

Guru dapat memulai dengan tanya jawab tentang rumah dan sekitar, seperti; Apa gunanya rumah? Apa saja yang ada di rumahmu? Apa yang ada di depan rumah? Bagaimana kalau rumah tidak berjendela, berpintu? Apa yang menarik di rumahmu? dan seterusnya.

Dari pertanyaan pancingan di atas, akan muncul ide-ide dari siswa tentang rumah dan ide-ide itu akan berkembang. Setelah hal itu terjadi, siswa dapat dikelompokkan untuk membahas tentang rumah sehat dan tidak sehat dengan alasan, kemudian di sampaikan di depan kelas. Kegiatan ini dapat berkembang secara luas, misalnya siswa ditugasi menulis ceramah singkat tentang rumah dan banyak lagi topik-topik lain yang dapat berkembang tanpa mengalami kesulitan.

\section{Gambar Rumah}

\section{Media Sains (IPA)}

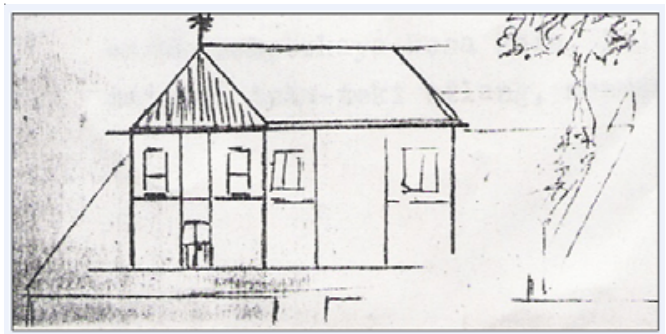

Gambar 2. Rumah

Media sains (IPA) sangat menarik digunakan dalam pembelajaran bahasa Indonesia SD. Hal ini 
sangat mendukung pembelajaran konkrit dan manipulatif. Misalnya, setelah selesai praktikum baik fisika, biologi dan lainnya, siswa ditugasi menyusun laporan (fokus menulis). Fokus berbicara dapat dengan menyusun bahan ceramah seperti: "Memanfaatkan Tenaga Air". Kegiatan pembelajaran di atas dapat dilaksanakan setelah pelaksanaan pembelajaran sains dengan menggunakan pengamatan lingkungan sekitar sebagai pusat sumber belajar, untuk kelas IV ke atas (kelas tinggi SD).

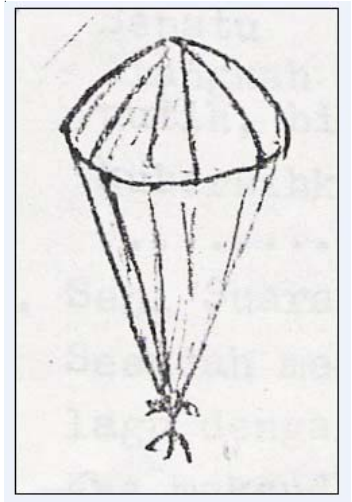

Gambar 3. Parasut

Selanjutnya, contoh lain;

Tema/subtema : Teknologi Sederhana/Parasut

Pembelajaran : Menjelaskan sifat Udara

Aspek/Fokus : Berbicara

Indikator : : Mengidentifikasi masalah-masalah aktual yang ada di lingkungan.

Untuk kelas tinggi, siswa dapat diarahkan untuk mengidentifikasi mengapa parasut tidak langsung terjatuh waktu dilemparkan ke atas? Apa fungsi parasut? Apa pula kegunaannya bagi kehidupan manusia? Siswa diberi tugas menjelaskan dengan menggunakan bahasa yang baik.

Bagi kelas rendah (I, II, III), dapat dimulai pembelajaran dengan mengamati bermacam-macam bangun, untuk memperkaya kosa kata. Lalu membuat kalimat sederhana atau mengisi teka-teki silang, mendeskripsikan sesuatu benda dan lain-lain. Pembelajaran akan berkembang dengan lancar dari alat bantu yang konkrit, tanpa merasa kesulitan dalam memunculkan ide-ide.

\section{Media Seni}

\section{a. Seni Rupa}

Pembelajaran bahasa Indonesia di SD, yang dihubungkan dengan pembelajaran seni rupa akan sangat menarik dan hidup. Hal ini dapat dimulai, misalnya: Siswa kelas III atau kelas IV; Pembelajaran diawali dengan mengajak siswa membayangkan suatu berdasarkan pengalaman. Selanjutnya siswa diajak menggambar benda tersebut di dalam buku gambarnya masing-masing. Dari kondisi ini akan muncul ucapan siswa tentang benda-benda yang dimiliki atau benda yang diidamkan oleh siswa, seperti; sepatu baru, tas sekolah, baju, atau alat permainan, dan lain-lain. Siswa diajak menggambar salah satu benda tersebut sesuai dengan pilihannya (diberi waktu sekitar 30 menit). Setelah selesai menggambar, siswa diarahkan untuk menceritakan perasaannya terhadap benda tersebut. Perasaan itu, dapat diungkapkan dalam bentuk prosa/ fiksi atau puisi. Sebaiknya guru memberi contoh atau model, seperti di bawah ini:

Tema/subtema : Peristiwa/Peristiwa sehari-hari

Pembelajaran :Menceritakan Pengalaman

Indikator : : Menyampaikan/menuliskan tentang sesuatu sesuai dengan perasaan sendiri dengan pilihan kata/kalimat yang baik.

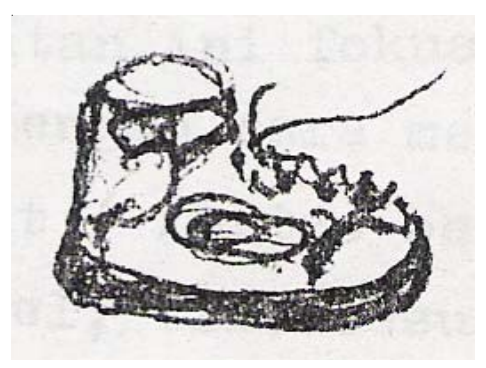

Gambar 4. Sepatu

\section{Sepatu}

Alangkah bagus rupamu

Putih, hitam dan biru

Kubersihkan kau setiap waktu

Ku senang memilikimu.

Bentuk puisi di atas dapat pula ditulis dalam bentuk prosa/fiksi.

\section{b. Seni Suara}

Sesudah pelajaran seni suara baik diiringi musik atau tidak, siswa diajak mencermati syair lagu dan dibimbing menghayatinya. Setelah itu diucapkan sesuai dengan penghayatan. Misal: Untuk kelas awal (I, II, III)

\section{Pelangi}

A. T. Mahmud

Pelangi-pelangi

Alangkah indahmu 


\section{Merah, kuning, hijau \\ Di langit yang biru \\ Pelukismu agung \\ Siapa gerangan? \\ Pelangi-pelangi \\ Ciptaan Tuhan.}

Untuk kelas tinggi (IV, V dan VI); Dari syair lagu di atas, siswa diajak menghayati, kemudian dapat menceritakan makna dari syair lagu yang terkandung di dalamnya, setelah itu diceritakan ke depan kelas/ atau secara tertulis. Dengan strategi seperti itu, maka siswa akan belajar dengan suka cita tanpa paksaan dan suasana menyenangkan. Ide-ide akan muncul dan berkembang dengan lancar. Guru hanya mengkondisikan dan memberi arahan serta contoh konkrit.

\section{c. Media Keterampilan Teknik}

Pembelajaran bahasa Indonesia dengan menggunakan media dalam pembelajaran keterampilan teknik pun dapat dilaksanakan dengan berbagai strategi. Hal ini sangat tergantung dengan kreativitas guru. Di sini penulis sajikan contoh sebagai berikut.

$\begin{array}{ll}\text { Mata Pelajaran } & \text { : Bahasa Indonesia } \\ \text { Tema/sub tema } & \text { : Kegemaran/Membuat } \\ & \text { Mainan Sendiri } \\ \text { Kompetensi Dasar } & \text { : Menjelaskan } \\ \text { Urutan/indikator } & \text { : Menjelaskan cara mem- } \\ & \text { buat mainan } \\ & \text { Menjelaskan cara } \\ & \text { melakukan permainan }\end{array}$

Kelas : III (tiga)

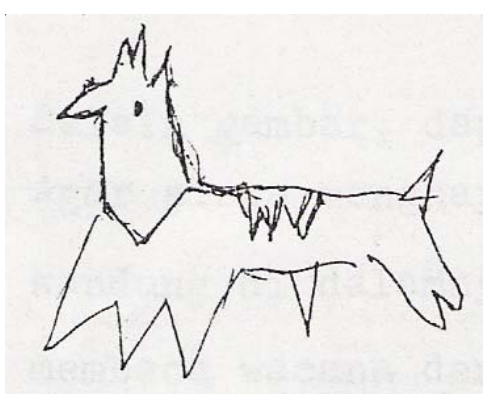

Gambar 5. Mainan kuda-kudaan

Pelaksanaan Pembelajaran dapat dilakukan sebagai berikut.

a. Siswa diajak mengamati alat mainan yang diperlihatkan guru (mainan kuda-kudaan).

b. Guru melakukan tanya jawab dengan siswa; Ini apa? Alat permainan apa? Terbuat dari apa dan seterusnya. c. Siswa diajak memprediksi bagaimana kira-kira cara membuatnya?

d. Bahan-bahan yang diperlukan apa saja.

e. Selanjutnya siswa diberikan bacaan yang berisi petunjuk singkat tentang cara membuat permainan.

f. Setelah itu siswa dibagi kelompok 3-5 orang, untuk membuat petunjuk membuat alat permainan sesuai dengan apa yang diketahuinya, dan bagaimana cara memainkannya. Tuliskan dengan baik dan berurutan.

Untuk pertemuan berikutnya, siswa dapat mendramatisasikan permainan tersebut. Dari contoh di atas, masih banyak kreasi proses pembelajaran yang mengembangkan beberapa keterampilan, sesuai dengan kreativitas yang dimunculkan guru. Jadi dengan media dapat dijadikan sumber belajar, yang dapat dikembangkan dengan menyenangkan dan variatif.

\section{d. Media Olah Raga.}

Selain media-media dalam beberapa mata pelajaran di atas, media olah raga pun dapat digunakan sebagai media dalam pembelajaran bahas Indonesia.

\section{Kelas \\ Tema/ Subtema \\ : V (lima) \\ Kompetensi Dasar \\ : Permainan/ Bermain Bola \\ : Mendeskripsikan benda/ alat \\ Indikator \\ : Menguraikan benda/alat dari segi manfaat atau kelemahannya.}

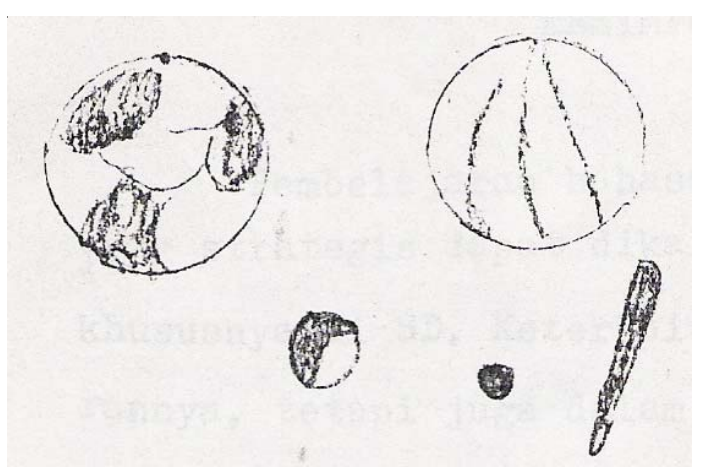

Gambar 6. Alat olah raga

Pelaksanaan Pembelajaran dapat dilakukan sebagai berikut.

a. Guru dapat memulai dengan pertanyaan pancingan; Apa kegiatan positif yang dapat kalian lakukan untuk mengisi waktu luang? Antara lain jawaban siswa: "Bermain, Bu, jalan-jalan! " dsb.

b. Dilanjutkan dengan memperlihatkan berbagai bentuk bola dari yang kecil (bola bekel) sampai yang 
besar (bola basket). Kegiatan ini dapat dilakukan di gedung olah raga (jika SD memilikinya) atau dapat pula dilakukan di kelas dengan penataan yang mendukung.

- Siswa dikelompokkan dan diberi beberapa bola dalam tiap satu kelompok.

- Kepada siswa diberi LKS dan mengerjakan LKS tersebut, yang isinya antara lain

1. Menjelaskan bola apa itu? bagaimana gerakan dalam permainannya?, bagaimana aturan bermainnya? Apa saja yang dianjurkan dan dilarang? Apa manfaat permainan itu? dan berapa orang pemainnya? Semua penjelasan harus ditulis dengan bahasa yang baik dan komunikatif.

2. Kegiatan di atas dilanjutkan sesuai dengan alokasi waktu dan dapat dikembangkan secara terpadu dengan berbagai variasi yang menyenangkan dan menantang.

\section{KESIMPULAN DAN SARAN}

Pembelajaran bahasa Indonesia sebagai pelajaran yang strategis dapat dikaitkan (secara terpadu) dengan semua pelajaran, khususnya di Sekolah Dasar. Keterpaduan itu, bukan saja dalam materi pembelajarannya, tetapi juga dalam media pembelajaran. Hal ini memang telah tersirat dalam GBPP SD 1994/1995 dengan pendekatan terpadu, dan telah tersurat dalam Kurikulum SD (KBK 2004), khususnya untuk kelas awal SD. Namun pemahaman guru terhadap pelaksanaan pendekatan pembelajaran terpadu masih sangat terbatas. Lebih-lebih lagi pemahaman siswa terhadap penggunaan media terpadu.

Sehubungan dengan hal di atas, maka melalui makalah ini penulis menyarankan agar guru SD khususnya, dan guru pada umumnya dapat mengupayakan media/ alat bantu melaksanakan proses pembelajaran. Salah satu cara yang efektif dalam pengadaan media adalah dengan menerapkan penggunaan media terpadu. Karena itu perlu adanya koordinasi antar berbagai bidang studi. Dengan demikian diharapkan pembelajaran di SD khususnya, dapat terlaksana dengan baik dan mencapai hasil yang optimal. Pada akhirnya, peningkatan mutu pendidikan seperti yang diharapkan bangsa dapat tercapai, walaupun pencapaiannya secara bertahap.

Perlu disadari betul, bahwa dengan bantuan media, pembelajaran dapat berlangsung secara variatif dan guru dapat memberi pengalaman baru. Media dapat berfungsi pula sebagai sumber belajar, yang dapat berkembang secara terpadu sesuai dengan kebutuhan siswa dalam rangka mencapai kompetensi yang telah digariskan dalam kurikulum. Jadi guru harus selalu menyadari dan berupaya terus-menerus agar dapat menciptakan kondisi belajar yang kreatif dan menyenangkan. Salah satu saran untuk mencapainya adalah dengan bantuan media secara terpadu.

\section{DAFTAR PUSTAKA}

Anderson, R. H. Pemilihan dan pengembangan media untuk pembelajaran. Jakarta: UT dan Pusat Antaruniversitas di UT.

Arsyad, A. (2006). Media pembelajaran. Jakarta: PT. Grafindo Persada.

Akhadiah, S. (1996). Pembelajaran bahasa indonesia SD. Jakarta: Laporan Penelitian, FPBSI IKIP.

Depdiknas. (2004). Kurikulum SD dan MI berbasis kompetensi. Jakarta: Departemen Pendidikan Nasional.

Depdikbud. (1997). Proyek pengembangan guru SD: Program pembelajaran terpadu. Jakarta: Depdikbud, Dikti.

Iskandar, S. (1995). Kecenderungan di SD. Jakarta: Depdikbud, Dirjen Dikti, Bag. Proyek Pengembangan PGSD.

Mulyasa, E. (2005). Menjadi guru profesional. Bandung: Remaja Rosda Karya.

Jameel, J. (2005). Pendidik yang sukses. Jakarta: Hikmah.

Neuaran, D. B. (1993). Experiencing elemantary science. California: Wadworth Publishing Company.

KETERANGAN PENULIS

Zulela M.S, M.Pd., lahir di Palembang tahun 1953, saat ini bekerja sebagai staf pengajar untuk program studi PGSD FIPUNJ. Terakhir menyelesaikan pendidikan program S2 bidang Pendidikan Bahasa UNJ. Salah satu artikel ilmiah yang pernah ditulisnya yaitu Teknik yang Tepat dalam Keterampilan Berbicara dan Kemampuan Menulis Guru SD di Jakarta, keduanya dimuat di jurnal DIKTI. 